\title{
Study Protocol Version Phase Code
}

National Cancer Institute

\section{Source}

National Cancer Institute. Study Protocol Version Phase Code. NCI Thesaurus. Code C94118.

A coded value specifying the designation of approval phase for a study. 